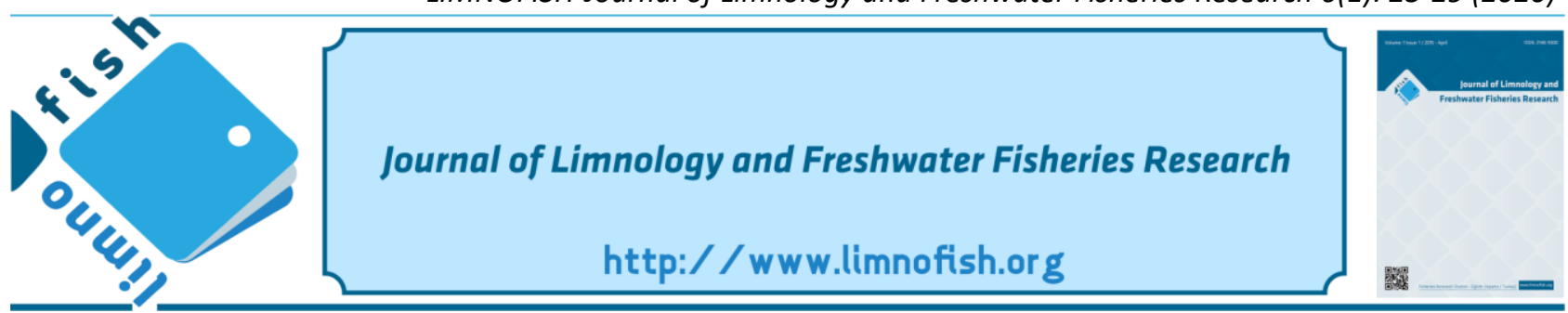

\title{
The Effects of Different Stunning Techniques on Blood Biochemistry of Brown Trout (Salmo trutta fario)
}

\author{
Muhammed ATAMANALP ${ }^{1}$ (D), Murat GENÇ2 (D), Gonca ALAK $^{1^{*}}$ (D), Nilüfer SABUNCUOĞLU ${ }^{2}$ (D), \\ Esat Mahmut KOCAMAN ${ }^{1}$ (D) Ömer ÇOBAN ${ }^{2}$ (D), Asuman ÖZKAN ${ }^{3}$ (D), Ziya Gökalp CEYLAN ${ }^{4}$ (D)
}

${ }^{1}$ Department of Aquaculture, Faculty of Fisheries, Atatürk University, TR-25240 Erzurum, Turkey

${ }^{2}$ Department of Zootechny, Faculty of Veterinary, Atatürk University, TR-25240 Erzurum, Turkey

${ }^{3}$ Department of Biochemistry, Regional Education Hospital, TR-25240 Erzurum, Turkey

${ }^{4}$ Department of Food Technology, Faculty of Veterinary, Atatürk University, TR-25240 Erzurum, Turkey

\section{A B STR ACT}

In this study, physiological responses of brook trout (Salmo trutta fario) were researched after the different stunning methods with biochemical enzymes. Icy water, electroshock, $\mathrm{CO}_{2}$, hypoxia, and head hitting were tried as stunning techniques to 75 fish and the alterations in the blood biochemistry parameters were analyzed. Alkaline phosphates $(A L P)$, and amylase $(A M S)$ were found as not statistically important, but alanine transaminases (ALT), aspartate transaminases (AST), creatin chitinase $(C K), C K-M B$ (one of the $C K$ isoenzymes), gamma glutamil transferase $(G G T)$ and lactate dehydrogenase $(L D H)$ levels were important $(\mathrm{p}<0.05)$. According to these results, the different stunning techniques affected the stress levels and physiological situations of brook trout. The study findings showed that killing techniques resulting in a shorter period were more suitable for animal welfare.

Keywords: Brook trout, biochemistry, blood, stunning methods

\section{ARTICLE INFO}

\section{RESEARCH ARTICLE}

Received : :05.02.2019

Revised : :09.05.2019

Accepted : :31.05.2019

Published : 25.04.2020

DOI:10.17216/LimnoFish.522776

\section{* CORRESPONDING AUTHOR}

galak@atauni.edu.tr

Phone : +904422312178

\section{Farklı Öldürme Tekniklerinin Kahverengi Alabalık (Salmo trutta fario) Kan Biyokimyası Üzerine Etkileri}

Öz: Bu çalışmada, kahverengi alabalıklara (Salmo trutta fario) farklı öldürme teknikleri uygulanarak balıkların fizyolojik yanıtları bazı kan biyokimya enzimleri ile araştırılmıştır. Buzlu su, elektroşok, $\mathrm{CO}_{2}$, hipoksi ve kafasına vurma gibi farklı öldürme teknikleri, 75 balık kullanılarak denenmiş ve balıkların kan biyokimya parametrelerindeki değişim gözlemlenmiştir. Bu değişimlerde alkalin fosfataz $(A L P)$ ve amilaz $(A M S)$ istatistiki olarak önemsiz $(\mathrm{p}<0,05)$, kreatin kitinaz $(C K)$ ve $C K$ izoenzimlerinden olan $C K-M B$ enzimi $\mathrm{p}<0,05$ seviyesinde, alanin aminotransferaz $(A L T)$, aspartat aminotransferaz $(A S T)$, gama glutamil transferaz $(G G T)$ ve laktat dehidrogenaz $(L D H)$ ise $\mathrm{p}<0,05$ ' de önemli bulunmuştur. Sonuçlar, öldürme tekniklerinin kahverengi alabalıklarda stres kaynağ 1 olabileceğini ve fizyolojik durumlarında etkili olduğunu göstermektedir. Çalışma bulguları, daha kısa sürede sonuçlanan öldürme tekniklerinin hayvan refahı açısından daha uygun olduğunu göstermiştir.

Anahtar kelimeler: Kahverengi alabalık, biyokimya, kan, öldürme teknikleri

How to Cite

Atamanalp M, Genç M, Alak G, Sabuncuoğlu N, Kocaman EM, Çoban Ö, Özkan A, Ceylan ZG. 2020 The Effects of Different Stunning Techniques on Blood Biochemistry of Brown Trout (Salmo trutta fario). LimnoFish. 6(1): 25-29. doi: 10.17216/LimnoFish.522776

\section{Introduction}

Biological and environmental factors may cause stress in aquatic livings. These stress factors may be vital activities as well as various farm practices. Genetic, farm treatments, environmental factors, growth, malnutrition, hunger, stock and transport density, and deformities can be effective in the decreasein fish welfare (Conte 2004; El-khaldi 2010). In response to stress in aquatic organisms, especially fish are widely used in bio-indicator for observing the physical and chemical changes. Because of fish blood

results of the stress response in the right behalf of developing secondary effects of stress factors and ecosystem health, a fast and complete results (Kayhan et al. 2009; Atamanalp et al. 2012) Biochemical reactions are catalyzed by enzymes (Kiran et al. 2006). Stress factors provide expression with various metabolic findings such as hormonal, enzymatic and blood parameter alterations. It 
becomes possible to measure the stress levels in the livings with these parameters. Metabolic activities respond wholly when reached to the level of threshold interaction. The reason for this is that live metabolism works in harmony with the holistic balance.

The metabolic activities of living organisms may vary depending on various reasons in the process of natural life circulation and physical, biochemical, physiological troubles may occur. Stress is the interaction between the factors that make it and the defense reactions of the organism. The stress (internal or external) factors threaten the constant internal balance of the body in animals. The sources of stress are generally factors such as water temperature changes, oxygen deficiency, unsuitable fishing, and handling process. On the other hand, the biological stress factors include stocking density, microorganisms, macro-organisms, sex, other fish species, genetic background and life cycle of fish (Alak et al. 2010a).

The effects of stunning techniques on antioxidant enzyme activities, hematology, and food quality are widely studied (Cui et al. 2012; Botsoglou et al. 2014; Zampacavallo, et al. 2015; Chen et al. 2016; Zhang et al. 2017; Venturini et al. 2018). Because of the limited knowledge about how different stunning techniques affect the blood biochemistry, the stress mechanism and physiology of fish are not fully elucidated (Utrera and Estevez 2012).

The aim of this study is to determine the most suitable stunning technique for brown trout, levels of stress by examining the blood biochemistry parameters and to provide a reference to the studies to be done on this subject of the level.

\section{Materials and Methods}

Fish $(180 \pm 15 \mathrm{~g}$ weighing 75 brown trout (S. t. fario)) were obtained from Atatürk University Fisheries Faculty Inland Water Fish Species Treatment and Research Center, which had no infections and toxic history. Each group designed with 15 fish stockings.

\section{Stunning techniques}

Fish were grouped as, one for control others as treatments: Group I: Iced water (2/3 of total volume) (Urbieta and Gines 2000), Group II: electroshock (Roth et al. 2002), Group III: $\mathrm{CO}_{2}$ treatment, fish were placed in a saturated water tank with $\mathrm{CO}_{2}$ and gas flow continued throughout the trial (Roth et al. 2002) Group IV: Hypoxic group, accepted as the control group and hypoxia was applied, Group V: Impact on the fish head (Mishima et al. 2005).

Obtaining the blood samples, biochemical and statistical analyzes

Blood of fish samples were obtained from caudal vena with injection approximately $3 \mathrm{ml}$. placedon biochemical tubes. After centrifuged 10 minutes at $4000 \mathrm{rpm}$ (Bricknell et al. 1999), were analyzed with autoanalyzer for biochemical parameters (ALT, AST, ALP, $L D H, A M S, C K, C K-M B$ and $G G T$ ). The obtained data was applied variant analysis by using the SPSS software (Alak et al. 2010b).

\section{Results}

The effects of different stunning methods on the biochemical parameters of brown trout (S. t. fario) blood are shown in Tables 1 and 2.

Table 1. Biochemical values and statistical results.

\begin{tabular}{lcccc}
\hline GROUP & $\boldsymbol{A L P}(\mathbf{U} / \mathbf{L})$ & $\boldsymbol{A S T}(\mathbf{U} / \mathbf{L})$ & $\boldsymbol{A L T}(\mathbf{U} / \mathbf{L})$ & $\boldsymbol{L D H}(\mathbf{m g} / \mathbf{d l})$ \\
\hline Group I & $503.83 \pm 19.22^{\mathrm{a}}$ & $636.78 \pm 10.51^{\mathrm{a}}$ & $13.33 \pm 3.85^{\mathrm{ab}}$ & $1455.64 \pm 87.65^{\mathrm{ab}}$ \\
Group II & $438.54 \pm 13.45^{\mathrm{a}}$ & $524.50 \pm 13.19^{\mathrm{ab}}$ & $9.75 \pm 3.25^{\mathrm{b}}$ & $1189.10 \pm 47.16^{\mathrm{ab}}$ \\
Group III & $519.00 \pm 14.23^{\mathrm{a}}$ & $545.38 \pm 9.33^{\mathrm{ab}}$ & $14.25 \pm 9.69^{\mathrm{ab}}$ & $1790.64 \pm 26.83^{\mathrm{a}}$ \\
Group IV & $419.55 \pm 13.37^{\mathrm{a}}$ & $481.63 \pm 17.03^{\mathrm{b}}$ & $10.25 \pm 5.61^{\mathrm{b}}$ & $1403.00 \pm 42.91^{\mathrm{ab}}$ \\
Group V & $465.55 \pm 8.18^{\mathrm{a}}$ & $491.13 \pm 12.43^{\mathrm{b}}$ & $17.16 \pm 6.56^{\mathrm{a}}$ & $1081.63 \pm 74.90^{\mathrm{b}}$ \\
\hline
\end{tabular}

*Each value represents mean $\pm \mathrm{SD}(\mathrm{n}=15)$ there is no statistical difference between the values shown in the same column with the same letter $(a, b)(p<0.05)$.

Table 2. Biochemical values and statistical results.

\begin{tabular}{lcccc}
\hline GROUP & $\boldsymbol{A M S}(\mathbf{U} / \mathbf{L})$ & $\boldsymbol{C K}$ & $\boldsymbol{C K}-\boldsymbol{M B}$ & $\boldsymbol{G G T}(\mathbf{U} / \mathbf{L})$ \\
\hline Group I & $396.00 \pm 21.04^{\mathrm{a}}$ & $5635.92 \pm 408.42^{\mathrm{a}}$ & $2256.36 \pm 226.45^{\mathrm{b}}$ & $9.91 \pm 4.31^{\mathrm{a}}$ \\
Group II & $397.81 \pm 26.99^{\mathrm{a}}$ & $1683.70 \pm 144.81^{\mathrm{b}}$ & $2337.00 \pm 187.39^{\mathrm{b}}$ & $7.50 \pm 3.42^{\mathrm{a}}$ \\
Group III & $354.00 \pm 11.26^{\mathrm{a}}$ & $4998.50 \pm 198.56^{\mathrm{a}}$ & $5783.36 \pm 196.26^{\mathrm{a}}$ & $10.08 \pm 5.68^{\mathrm{a}}$ \\
Group IV & $255.18 \pm 15.53^{\mathrm{a}}$ & $1819.91 \pm 115.10^{\mathrm{b}}$ & $2579.11 \pm 168.44^{\mathrm{b}}$ & $8.25 \pm 4.03^{\mathrm{a}}$ \\
Group V & $359.90 \pm 25.86^{\mathrm{a}}$ & $3964.91 \pm 310.91^{\mathrm{ab}}$ & $2492.64 \pm 243.92^{\mathrm{b}}$ & $15.25 \pm 9.69^{\mathrm{b}}$
\end{tabular}

*Each value represents mean $\pm \mathrm{SD}(\mathrm{n}=15)$ there is no statistical difference between the values shown in the same column with the same letter $(a, b)(p<0.05)$. 
The nearest results to the control group (group IV; hypoxic) were obtained in group II (electroshock) and group $\mathrm{V}$ (impact on the fish head) in terms of $A L P, A S T, A L T$ and $L D H$.

The CK and CK-MB parameters, among the muscle enzymes, were observed the highest value in group I (iced water) and group III ( $\mathrm{CO}_{2}$ treatment). This situation showed that the highest stress conditions were found in these groups.

\section{Discussion}

Aquatic livings react to all stress factors in their living environment. These stress factors cause structural and functional disorders in fish blood cells and eritropetic tissues (Witeska and Baka 2002). As a result of the death of the cells, enzymes are released and as a result of sublethal damage, increases can be recorded with the increase of cell membrane permeability and exocytosis of the enzyme (Mert 1996).

Although there was no statistical difference between all groups for the $A L P$ value, the control group gave the lowest $A L P$ value with $419.55 \pm$ 133.70 (U / L). Apart from other enzymes, the increase in $A L P$ activity is induced by stimulation (Mert 1996). Similarly, lowest AST value was obtained in control group $481.63 \pm 170.30 \mathrm{U} / \mathrm{L}$, the highest $A S T$ value $636.78 \pm 105.09 \mathrm{U} / \mathrm{L}$ was in at iced water group and the differences were evaluated significant at the level of $p<0.05$.

Prior studies reported that muscle activities increase AST activity (Tekeli et al. 1996). Although there is no result for this value with a similar treatment in the literature scans made, it is thought that the observed increase in all values in the value group is related to severe muscle movements (Mert 1996).

$A L T$ and $L D H$ values were obtained statistically important in all groups $(\mathrm{p}<0.05)$. It is thought that the increase in serum bilirubin levels may be effective in groups in which elevation in $A L T$ level is more prominent (Özbek et al. 2006). Findings of the present research, especially $A S T$ values are similar to the findings which trained different stressors studies (Özbek et al. 2006; Gencer et al. 2015). When the $A S T, A L T$ and $A L P$ values are higher in the treatment groups than in the control group, it is thought that the inflammation resulting from stressors in the liver vessels is effective (Özbek et al. 2006). High $C K$ levels are effective at the cellular enzymes' increasing as $L D H$. This situation is an indicator of the answers to stress and deformation of muscles (Bórnez et al. 2009). Sabow et al. (2016) reported that high levels of $L D H$ are an important indicator of stress-related muscle fatigue and damage.
No data on fish was found in the literature scans for all the values on the chart, so, compared with heavy metal pollution, which is a different stressor. Firat and Inand1 (2016) reported that the concentrations of zinc, cadmium, zinc + cadmium increased the AST, ALT, $L D H$ and $A L P$ enzymes of Oreochromis niloticus. The values of $A L T, L D H$, and $A L P$ have increased in the present research, but not statistical importance $(\mathrm{p}>0.05)$. It has recently been recognized that $A S T$ and $A L T$ are indicative of liver cell damage (Gencer et al. 2015). The main synthesis site is the liver $A S T$ and $A L T$ gluconeogenic enzymes, which are not normally found in serum. Due to adaptation to ambient conditions, the energy requirement is not met from the carbohydrate sources, causing the enzyme synthesis to stop (Firat and Inand1 2016). Changes in AST levels are due to stress factors such as muscular dystrophy, muscle trauma, intramuscular injections, reproductive, hypoxia, stock intensity, and starvation, as well as toxic effects (Hilmy et al. 1985; Vijayan et al. 1997). As a result, whatever the type of stress, the negative effects on vital organs in the body are inevitable. If stress is not removed in time, irreversible damage to the body can occur. A significant increase was obtained in AST, ALT and ALP of the blood samples, obtained from the brown trout, which stunned with different methods in this research. It is known that the stress before death raises the lactate level. By death, catecholamines are released, resulting in the formation of hyperlactitemia as a result of muscle movement and rapid glycogenosis. Increasing the lactase level raises the levels (Svete et al. 2012).

Amylase is known as alpha-amylase (Mert 1996). While the differences among the groups of $A M S$ values were evaluated as not statistically important, the highest value $(359.90 \pm 258.59 \mathrm{U} / \mathrm{L})$ was obtained in a shot on the fish head. The lowest $A M S$ value belonged to the control group $255.18 \pm 155.28 \mathrm{U} / \mathrm{L}$.

As seen in Table 2, $C K-M B$ values of creatine chitinase and creatine chitinase isoenzymes were statistically significant $(\mathrm{p}<0.05)$ among all groups. The highest values for $C K$ and $C K-M B$ were belonged to the $\mathrm{CO}_{2}$ group as in order, 4998.50 \pm 1985.60 and 5783.36 \pm 1962.58 . Literature studies have been carried out in studies conducted with other species in which the $C K$ values increase with movement. Pre-cutting applications and cutting techniques are characterized by muscle enzymes $C K$ and $A S T$ measurements, which are characterized by their effect on the physiological response of the animals (Svete et al. 2012). Changes that involve physical activities before slaughter (jump, etc.) are in behavioral responses to stress conditions and cause muscle damage and muscle enzyme activities to 
increase with muscle damage (Boissy 1995; Winther et al. 2005; Svete et al. 2012). All groups' $C K$ and $A S T$ values are found higher than control in this research. This suggests that the stunning techniques cause muscle damage and thus increase the serum muscle enzymes. Significant increases in serum $C K$ and $A S T$ activities, however, may also be attributed partly to leakage of the enzyme from the skeleton. Muscle cells are damaged by rapid glycogenolysis induced by catecholamine or increased muscle damage and membrane permeability during slaughter (Svete et al. 2012).

Creatine kinase $(C K)$, which has three isoenzymes, is an enzyme found in skeletal, cardiovascular and brain, one of these isoenzymes, $C K-M B$ isoenzymium, which is located in the heart and skeleton and constitutes $20 \%$ of $C K$. This isoenzyme level raises the myocardia problems. Acute myocardial infarct, myocarditis, cause to increase $C K$ level with excessive activity (Vijayan et al. 1997; Werner and Gallo 2008). In our study, $5635.92 \pm 4084.22 C K$ value compared to the control for water + ice mixture, which is considered as hypothermia application, was higher than all groups. High $C K$ activity is an indication of cell muscle damage and muscle fatigue (Sabow et al. 2016)

$G G T$ is a more sensitive indicator than $A L P$ and it is evaluated parallel with ALP and $A L T$. This value raises more and faster than $A L P$. The highest $G G T$ score was $15.25 \pm 9.69(\mathrm{U} / \mathrm{L})$ in the group shot on the fish head as it is in the ALT group, and the difference between the groups within the value was found to be very important at $p<0.05$. In blood biochemistry, especially bilirubin and $A L P$ values are increased. However, there is an increase in $A S T, A L T$, and $G G T$ levels because of liver damage due to cholestasis (Nakyinsige et al. 2013).

Because of the investigation of the present research findings, no significant differences were found statistically between $A L P$ and $A M S$ values among the control and treatment groups, but significant changes were observed in respect of other blood biochemical parameters (AST, ALT, $L D H, C K$, $C K-M B$, and $G G T$ ) compared to the treatment and control groups. It is necessary to know the standard parameters of each fish species for use as an indicator of health. In this research, is thought to have contributed to the work to be done to identify the effects of different killing methods on fish welfare. Our results show that short-term killing techniques (Group II and IV) give better biochemical results in terms of $S$. t. fario. welfare and low-stress status.

\section{Acknowledgments}

This research was supported by Atatürk University with the $2010 / 152$ project.

\section{References}

Alak G, Erdogan O, Ciltas A. 2010a. Hsp-70 gene expression analyses in the different ages of rainbow trout. Kafkas Univ Vet Fak Derg. 16(Suppl-B):183187. doi:10.9775/kvfd.2009.757

Alak G, Hisar SA, Hisar O, Kaban G, Kaya M. 2010b. Microbiological and chemical properties of bonito fish (Sarda sarda) fillets packaged with chitosan film, modified atmosphere and vacuum. Kafkas Univ Vet Fak Derg. 16 (Suppl-A):S73-S80. doi:10.9775/kvfd.2009.1475

Atamanalp M, Kocaman EM, Ucar A, Alak G. 2012. Kadmiyum toksisitesine karşı humik asitin koruyucu etkisinin kahverengi alabalıklarda (Salmo trutta fario) araştırılması. Fen Edebiyat Dergisi. 14(1):405-415.

Boissy A. 1995. Fear and fearfulness in animals. Q Rev of Biol. 70(2):165-191. doi:10.1086/418981

Bórnez R, Linares MB, Vergara H. 2009. Systems stunning with $\mathrm{CO}_{2}$ gas on Manchego light lambs: Physiologic responses and stunning effectiveness. Meat Sci. 82(1):133-138. doi: 10.1016/j.meatsci.2009.01.003

Botsoglou E, Govaris A, Ambrosiadis L, Fletouris D, Botsoglou N. 2014. Effect of leaf (Olea europen L.) extracts on protein and lipid oxidation of long-term frozen n-3 fatty acids-enriched pork patties. Meat Sci. 98: $150-157$. doi:10.1016/j.meatsci.2014.05.015

Bricknell IR, Bowden TJ, Bruno DW, MacLachlan P, Johnstone R, Ellis AE. 1999. Susceptibility of atlantic halibut, Hippoglossus hippoglossus (L) to infection with typical and atypical Aeromonas salmonicida. Aquaculture. 175(1):1-13. doi: 10.1016/S0044-8486(99)00025-3

Chen L, Li C, Ullah N, Guo Y, Sun X, Wang X, Feng X. 2016. Different physicochemical, structural and digestibility characteristics of myofibrillar protein from PSE and normal pork before and after oxidation. Meat Sci. 121: 228-237. doi: 10.1016/j.meatsci.2016.06.010

Conte, F.S. 2004. Stress and the welfare of cultured fish. Appl Anim Behav. Sci. 86 (3-4): 205-223. doi: 10.1016/j.applanim.2004.02.003

Cui X, Xiong YL, Kong B, Zhao X, Liu N. 2012. Hydroxyl radical-stressed whey protein isolate: Chemical and structural properties. Food and Bioprocess Techn. 5(6): 2454-2461. doi: 10.1007/s11947-011-0515-9

El-Khaldi ATF. 2010. Effect of different stress factors on some physiological parameters of Nile tilapia (Oreochromis niloticus). Saudi J Biol Sci. 17(3):241246.

doi: 10.1016/j.sjbs.2010.04.009

Firat O, Inandı AŞ. 2016. Biochemical toxicity of mercury and protective effect of zeolite on this toxicity in Oreochromis niloticus. TrJFAS. 31(2):86-95. doi: 10.18864/TJAS201610

Gencer YG, Cinar A, Comba B. 2015. Stresin ratlarda bazı karaciğer enzimleri (AST, ALT, ALP) üzerine 
etkilerinin araştırılması. Atatürk Üniversitesi Vet Bil Derg. 10(1):21-26.

Hilmy AM, Shabana MB, Daabes AY. 1985. Effects of cadmium toxicity upon the in vivo and in vitro activity of proteins and five enzymes in blood serum and tissue homogenates of Mugil cephalus. Comp Biochem Physiol Part C. 81(1): 145-153. doi: 10.1016/0742-8413(85)90106-9

Kayhan FE, Muslu MN, Koc ND. 2009. Stress and biological responses seen in aquatic organisms due to some trace elements. J Fisheries Sci. 3(2):153-162. doi: 10.3153/jfscom.2009019

Kıran ÖE, Comlekcioglu U, Dostbil N. 2006. Some microbial enzymes and usage fields in the industry. KSU J Sci Engin. 9(1):12-19.

Mert N. 1996. Veteriner Klinik Biyokimya. Bursa: Uludağ Üniversitesi Veteriner Fakültesi Yayını Ders Kitabı 288s.

Mishima T, Nonaka T, Okamoto A, Tsuchimoto M, Ishiya T, Tachibana K, Tsuchimoto M. 2005. Influence of storage temperatures and killing procedures on postmortem changes in the muscle of horse mackerel caught near Nagasaki Prefecture, Japan. Fisheries Sci. 71(1):187-194. doi:10.1111/j.1444-2906.2005.00947.x

Nakyinsige K, Man YB, Aghwan ZA, Zulkifli I, Goh YM, Abu Bakar F, Al-Kahtani HA, Sazili AQ. 2013.Stunning and animal welfare from Islamic and scientific perspectives. Meat Sci. 95(2): 352-61. doi: 10.1016/j.meatsci.2013.04.006

Özbek H, Cengiz N, Him A, Uğraş S, Özgökçe F, Erdoğan E. 2006.Yüksek kolesterollü diyetle beslenen sıçanlarda Thymus fallax F. (kekik) yapraklarının kan kolesterol seviyesi üzerine etkisi. Van Tip Derg. 13 (3): 71-77.

Roth B, Moeller D, Veland JO, Imsland A, Slinde A. 2002. The effect of stunning methods on rigor mortis and texture properties of atlantic salmon (Salmo salar). J Food Sci. 67(4): 1462-1466. doi: 10.1111/j.1365-2621.2002.tb10306.x

Sabow AB, Gohb YM, Zulkifli I, Sazili AQ, Kaka U, Ab Kadi MZA, Ebrahimi M. 2016. Blood parameters and electroencephalographic responses of goats to slaughter without stunning. Meat Sci. 121: 148-155. doi: 10.1016/j.meatsci.2016.05.009

Svete AN, Čebulj-Kadunc N, Frangez R, Kruljcteve P. 2012. Serum cortisol and haematological, biochemical and antioxidant enzyme variables in horse blood sampled in a slaughterhouse lairage, immediately before stunning and during exsanguination. Animal. 6(8):1300-1306. doi:10.1017/S1751731112000079
Tekeli SK, Ormen A, Mengi A. 1996.Safkan arap ve ingiliz taylarında serum AST, ALT ve ALP aktiviteleri üzerinde çalışmalar. İstanbul Üni Vet Fak Derg. 22(1):127-133.

Urbieta C, Gines R. 2000. Optimisation of slaughtering method in gilthead sea bream (Sparus aurata) industrial application in fish farms. Global quality assessment in Mediteranean aquaculture, Zaragosa. CHIEAM-IAAZ, Spain.

Utrera M, Estevez M. 2012. Oxidation of myofibrillar proteins and impaired functionality: Underlying mechanisms of the carbonylation pathway. J Agr Food Chem. 60(32): 8002-8011. doi: $10.1021 / j f 302111 \mathrm{j}$

Venturini FP, Vargas Baldi SC, Paris G, Costa TD, Rucin Que DS, Melo MP, Macedo Viegas EM. 2018. Effects of different stunning methods on blood markers and enzymatic activity of stress responses of tilapia (Oreochromis niloticus). Ital J Anim Sci. 17(4): 10941098. doi: 10.1080/1828051X.2018.1426396

Vijayan MM, Pereira C, Grau EG, Iwama GK. 1997. Metabolic responses associated with confinement stress in Tilapia: the role of cortisol. Comp Biochem Phys C. 116 (1): 89-85. doi: 10.1016/S0742-8413(96)00124-7

Werner M, Gallo C. 2008. Effects of transport, lairage and stunning on the concentrations of some blood constituents in horses destined for slaughter. Livest Sci. 115: 94-98. doi: 10.1016/j.livsci.2007.12.023

Winther Christensen J, Kelling LJ, Lindestrøm Nielsen B. 2005. Responses of horses to novel visual, olfactory and auditory stimuli. Appl Anim Behav Sci. 93(12):53-65. doi: 10.1016/j.applanim.2005.06.017

Witeska M, Baka I. 2002. The effect of long-term cadmium exposure on common carp blood. Fresen Environ Bull. 11(12A): 1059-1065.

Zampacavallo G, Parisi G, Mecatti M, Lupi P, Giorgi G, Poli BM. 2015. Evaluation of different methods of stunning/killing sea bass (Dicentrarchus labrax) by tissue stress/quality indicators. J Food Sci Technol. 52(5): 2585-2597. doi: $10.1007 / \mathrm{s} 13197-014-1324-8$

Zhang L, Li Q, Lyu J, Kong C, Song S, Luo Y. 2017. The impact of stunning methods on stress conditions and quality of silver carp (Hypophthalmichthys molitrix) fillets stored at 4 degrees C during $72 \mathrm{~h}$ postmortem. Food Chem. 216:130-137. doi: 10.1016/j.foodchem.2016.08.004 